Doris Delić, mag. oec.

ddelic03@gmail.com

izv. prof. dr. sc. Mario Pepur

Ekonomski fakultet, Sveučilište u Splitu, Split, Republika Hrvatska

mpepur@efst.hr

\title{
UTJECAJ SEGMENTACIJE NAVIJAČA NA NAMJERU PONOVNE KUPNJE
}

Primljeno: 13. veljače 2020.

Prihvaćeno: 26 . kolovoza 2020.

https://doi.org/10.46458/27121097.2020.26.29

\section{Prethodno priopćenje}

\section{Sažetak}

Zadnja dva desetljeća događa se velika i slojevita transformacija sporta u posao koja sportsku industriju svrstava među najznačajnije gospodarske grane razvijenog svijeta. Rastuća primjena recentnih načela poslovanja u sportskoj industriji neminovna su posljedica današnjeg poimanja sporta. Sportska industrija podrazumijeva globalno tržište različitih proizvoda i usluga povezanih sa sportom. Kako bi proizvođači i pružatelji sportskih proizvoda i usluga stvorili određene prednosti pred ostalim konkurentima prisiljeni su istražiti postojeće tržište te napraviti segmentaciju. Pod segmentacijom se podrazumijeva podjela potrošača u pojedine skupine na temelju njihovih karakteristika, preferencija i želja. Samo zadovoljni kupci razvijaju lojalnost prema proizvođaču ili pružatelju usluga te kao takvi učestalo ponavljaju svoju kupnju. Podaci korišteni u radu prikupljeni su istraživanjem među navijačima HNK Hajduka. U radu su se analizirali segmenti navijača te se istražila razlika između korištenih segmenata na namjeru ponovne kupnje. Testirane su razlike među segmentima u odnosu na namjeru ponovnog dolaska na utakmicu, namjeru ponovne kupnje proizvoda i usluga kluba i namjeru ponovne kupnje proizvoda i usluga sponzora kluba. Rezultati dobiveni istraživanjem ukazali su kako se navijači mogu grupirati u pet različitih segmenata te kako postoji statistički značajna razlika među segmentima u namjeri ponovne kupnje.

Ključne riječi: sportski marketing, segmentacija tržišta, namjera ponovne kupnje, nogometni navijači;

JEL: M31 


\section{UVOD}

Jedna od najprofitabilnijih i najinteresantnijih gospodarskih grana u svijetu je industrija sporta (Deloitte, 2020.). Milijarde ljudi diljem svijeta prate različite sportove, odlazeći na različita sportska događanja pritom trošeći milijarde eura na proizvode i usluge povezane sa omiljenim sportom, ligom, klubom, igračem itd. Industrija sporta postaje još značajnija uz činjenicu kako se mnoštvo različitih proizvoda i usluga različitih gospodarskih grana mogu uspješno promovirati putem sporta i njegove globalne popularnosti. Iako je maksimalizacija profita jedan od temeljnih poslovnih ciljeva, industriju sporta ipak određuje sportska aktivnost te društvena potreba uključivanja široke mase ljudi u bavljenje fizičkim aktivnostima, a ne samo uživanju u sportu kao zabavnoj aktivnosti. Zahvaljujući snažnom razvoju industrije sporta pruža se mogućnost promatranja različitih sportova, posebice nogometa, u potpuno novoj dimenziji.

Nužno je razumjeti ponašanje korisnika sportskih usluga te razlikovati korisnike u skladu s njihovim vrijednostima, stavovima i ponašanjima prema određenom sportu. Nisu svi korisnici podjednako strastveni navijači niti se poistovjećuju sa timom za koji navijaju. Svaki od njih doživljava sport na različite načine i koriste svoje timove kako bi zadovoljili širok raspon vlastitih potreba. Detaljna segmentacija korisnika pomaže marketinškim stručnjacima kod usavršavanja marketinških aktivnosti, redizajniranju sportskih proizvoda i usluga, praćenju osjetljivosti potrošača na cijene, preuređenju sportskih objekata, oblikovanju adekvatnih promotivnih akcija i prilagodbi sportskih doživljaja i iskustava potrebama pojedinog segmenta korisnika.

Predmet istraživanja rada je segmentacija baze navijača HNK Hajduka te ispitivanje razlika među segmentima u odnosu na namjeru ponovne kupnje. U okviru navedenog istražiti će se utjecaj segmentacije na namjeru ponovnog dolaska na utakmice, kupovinu proizvoda HNK Hajduka te kupovinu proizvoda i usluga sponzora HNK Hajduka. Istraživanja u području sportskog marketinga su uzela velikog maha u svijetu i predstavljaju vrlo intenzivno i atraktivno područje za marketinške stručnjake za razliku od RH gdje značajniji razvoj sportskog marketinga tek slijedi. Glavni doprinos rada je u isticanju važnosti potrebe za dobrom segmentacijom tržišta i boljem razumijevanju motiva navijača kako bi što bolje opslužili postojeće tržište. Rezultati bi trebali dati marketinškim stručnjacima određene smjernice pri kreiranju ponuda za različite segmente te ukupnom povećanju profita u budućnosti. Posljednja intencija ovog rada je da potakne akademsku i stručnu javnost na istraživanja u ovom području. 


\section{TEORIJSKI OKVIR}

Sport se u životu ljudi nalazi od davnina zbog višestrukih pozitivnih utjecaja na čovjeka kao pojedinca ali i na cjelokupno društvo. Neosporna činjenica je ta kako je upravo marketing zaslužan za planetarnu popularnost pojedinih sportova, prvenstveno nogometa, te kao takav sportski marketing predstavlja sve zanimljivije područje za daljnja istraživanja.

Popularizacija i globalizacija nogometa doprinijela je sve većoj potrebi za kvalitetnom segmentacijom navijača. Navijači predstavljaju vrlo važan dio poslovanja kluba iz razloga što upravo zbog njih igrači, treneri, uprave i sponzori zarađuju ogromne količine novca. Zagnoli i Radicchi (2010., 79-84) smatraju navijače najvažnijim čimbenikom korištenja sportske usluge. Sportsko uzbuđenje i strast navijača te njihovo sudjelovanje na utakmicama igra odlučujuću ulogu u samoj provedbi događaja i stvaranju vrijednosti. Autori navijače, kao direktne korisnike sportske usluge, smatraju važnom ekonomskom vrijednošću s obzirom da o njihovom zadovoljstvu uvelike ovise prihodi kluba. Dijele navijače na tri segmenta s obzirom na njihova socio-demografska obilježja. Prvi segment nazivaju ,temeljni navijači“ (engl. The core fans) te ih opisuju kao glavne navijače koji učestalo prisustvuju utakmicama, vrlo su aktivni i vjerni, uglavnom su muškog roda, većinom imaju završenu srednju školu te pripadaju srednjem društvenom sloju. Drugi segment, „mladi ljudi“ (engl. The young people), većinom čine studenti koji se povode i dive „temeljnim navijačima“, vrlo su aktivni, uživaju u pobijedi svoga kluba te imaju mala mjesečna primanja. Posljednji, treći segment, nazivaju „seniori““ (engl. The seniors) koji čine navijači stariji od 45 godina, zreliji su od prethodna dva segmenta, gledaju utakmice uglavnom sami ili u manjim skupinama te ih više zanima sigurnost i udobnost tijekom gledanja utakmice.

Kosciolek i Nessel (2019., 154-176) su napravili segmentaciju nogometnih navijača u Poljskoj. Koristeći tri bihevioralne varijable: identifikacija navijača, zadovoljstvo rezultatima nogometnog kluba te uključenost putem društvenih medija klaster analizom su dokazali postojanje četiri segmenta nogometnih navijača koji se međusobno razlikuju na temelju demografskih karakteristika (spola i starosti navijača) te četiri osnovna elementa kupovnih navika (dolazak na utakmicu, kupnja proizvoda kluba i sponzora, uključenost u društvene medije, interes za medijsku pokrivenost). „Strastveni obožavatelji“ (engl. The avid fans) su najmlađa skupina koju karakterizira najveća uključenost i privrženost klubu, za razliku od „povremenih navijača“ koji su najmanje emocionalno privrženi klubu te koji troše najmanje iznose u odnosu na preostale segmente navijača. „Okorjeli navijači“ (engl. The die-hard fans) su kao i „redoviti gledatelji“ (engl. Regular) najčešći posjetitelji nogometnih utakmica, ali ujedno i najnezadovoljnija skupina rezultatima svoje nogometne momčadi. Kod oba segmenta, pripadnost klubu je važan dio njihove samoidentifikacije. 
Zadnjih godina nekolicina autora je temeljem različitih kriterija segmentirala navijače. Fisher (2019.) je koristila pristup segmentaciji navijača temeljen na vrsti društvene mreže koju navijači koriste te motivaciji korištenja same mreže. Neki drugi, poput Kim i dr. (2016.), su primijenili višekriterijski pristup pri segmentaciji tržišta koji se bazirao na motivaciji navijača, njihovom zadovoljstvu te različitim demografskim karakteristikama. Agas i dr. (2012., 112) smatraju kako svrstavanje navijača sa sličnim preferencijama i kupovnim ponašanjem u pojedine segmente pruža istovremeno bolje razumijevanje potrošača i razvijanje konkurentskih prednosti. Jedino razumijevanje različitih tržišnih segmenata može omogućiti marketinškim stručnjacima da razviju prikladne strategije za privlačenje novih i zadržavanje postojećih gledatelja. Istraživanje navedenih autora, kao i istraživanje u ovom radu, provedeno je po uzoru na rad Hunt-a (1999.). On uočava kako ponašanje navijača i nivo povezanosti s klubom nije kod svih na istoj razini. Navijače svrstava prema njihovoj motivaciji i ponašanju u pet različitih segmenata: „fanatični navijač“ (engl. The fanatical fan), ,predani navijač“ (engl. The devoted fan), „disfunkcionalni navijač“ (engl. The dysfunctional fan), „lokalni navijač“ (engl. The local fan; ,predani lokalni navijač“ i „privremeni lokalni navijač“) te ,privremeni navijač“" (engl. The temporary fan).

Današnji proizvođači i pružatelji usluga nastoje zadržati postojeće i privući nove kupce i korisnike kako bi uspjeli opstati na sve konkurentnijim tržištima. Samo zadovoljni kupci razvijaju lojalnost prema proizvođaču ili pružatelju usluga te kao takvi učestalo ponavljaju svoju kupnju. Prema Oliveru (1997., preuzeto od Kim i dr., 2011., 37) namjera ponovne kupnje označava namjeru korisnika da ponovno kupi proizvod ili uslugu. Isti autor je definirao namjeru ponovne kupnje kao namjeru ponovljenih kupnji proizvoda ili usluga temeljeno na prethodnom pozitivnom iskustvu i budućem očekivanju. Olaru i dr. (2008., 556) nadodaju kako namjera ponovne kupnje od strane korisnika ovisi o vrijednosti koju su dobili od prijašnjih transakcija (Wathne i dr., 2001.; Bolton i dr., 2000.) od kojih se ističu: odgovarajući kriterij performansi, konkurencija, te sam troškovni aspekt. U ovom radu pod namjerom ponovne kupnje se konkretno misli na ponovni dolazak na utakmicu, kupovinu proizvoda HNK Hajduka i kupovinu proizvoda sponzora HNK Hajduka.

Zadovoljstvo kupaca ovisi o ispunjenju željenih očekivanja. Zadovoljstvo je osjećaj ugode ili razočaranja koji rezultira usporedbom očekivanih, te stvarnih, tj. dobivenih vrijednosti proizvoda. Današnji proizvođači i pružatelji usluga ciljaju na visoku razinu zadovoljstva jer se samo zadovoljan kupac može odlučiti na ponovnu kupnju proizvoda i usluga (Kotler, 2001., 102). Boonlertvanich (2009., 3) navodi kako su brojni autori u svojim istraživanjima zadnjih trideset godina dokazali da je namjera ponovne kupnje ključni faktor profitabilnosti poduzeća te se treba smatrati strateškim ciljem poduzeća. Korisnici koji ponovno koriste proizvode ili usluge određenog poduzeća značajno doprinose profitu tog poduzeća 
budući zahtijevaju manje vremena i pažnje za razliku od korisnika koji prvi puta koriste proizvod ili uslugu.

\section{MODEL ISTRAŽIVANJA}

\subsection{Hipoteze istraživanja}

Analiziranjem dostupne literature te sukladno predstavljenoj problematici postavljene su temeljne istraživačke hipoteze, jedna glavna hipoteza te tri pomoćne hipoteze.

H1: Postoji značajna razlika među segmentima navijača u namjeri ponovne kupnje.

H1.1.: Postoji značajna razlika među segmentima navijača u namjeri ponovnog dolaska na utakmicu.

H1.2.: Postoji značajna razlika među segmentima navijača u namjeri kupnje proizvoda HNK Hajduka.

H1.3.: Postoji značajna razlika među segmentima navijača u namjeri kupnje proizvoda i usluga sponzora HNK Hajduka.

Slika 1. Model utjecaja segmentacije gledatelja na namjeru ponovne kupnje

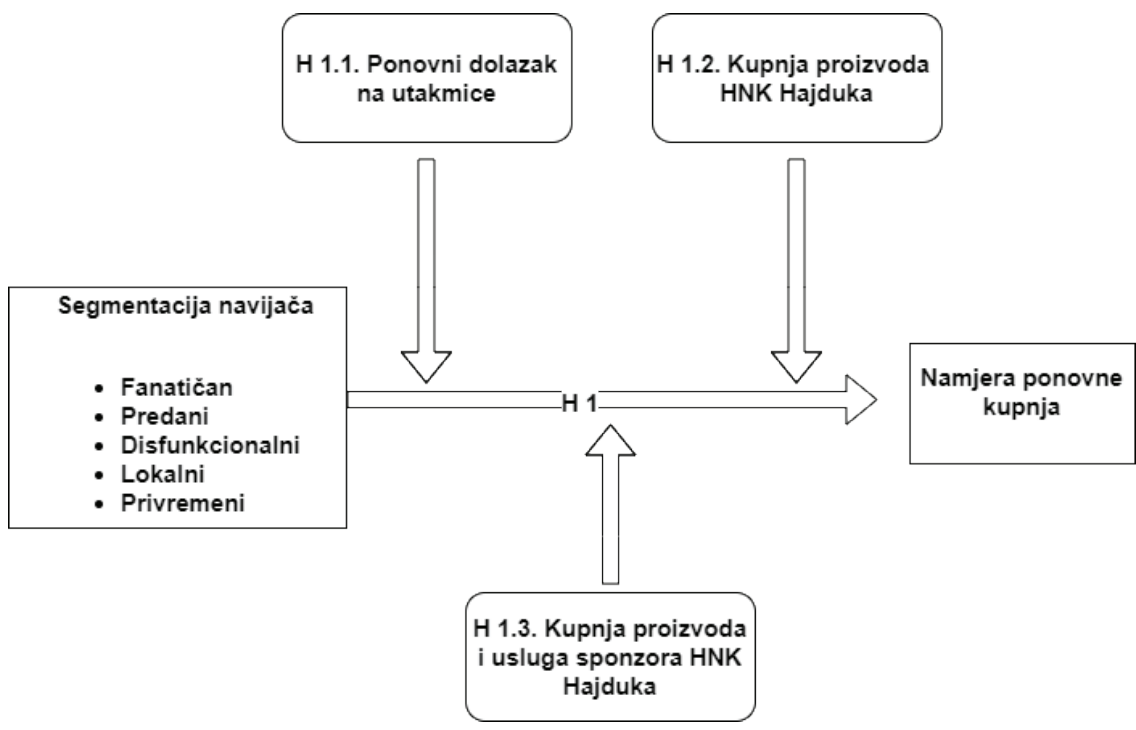

Izvor: Istraživanje autora 


\subsection{Metodologija istraživanja}

Primarni podaci su prikupljeni kroz jednokratno deskriptivno istraživanje na namjernom uzorku od 283 ispitanika. Empirijsko istraživanje je provedeno metodom ispitivanja koristeći se znanstveno utemeljenim anketnim upitnikom kao glavnim instrumentom istraživanja. Korištene tehnike i metode obrade podataka su prikazane po fazama: prikupljeni podaci su uz pomoć programskih alata prekodirani i pripremljeni za daljnju obradu; korištene su metode deskriptivne statistike; redoslijedna skala mjerenja te je ispitana razlika između pet nezavisnih uzoraka uz pomoć Kruskal-Wallis testa. Anketiranje je provedeno putem interneta. Izabrana je ova vrsta medija za provođenje ispitivanja poradi lakšeg dolaska do većeg broja ispitanika i bržeg provođenja samog anketnog upitnika.

Upitnik je konceptualno oblikovan referirajući se na znanstveni rad autora Agas i dr. (2012.) koji definiraju podjelu navijača na pet segmenata te navode karakteristike istih. Spomenuti autori su kreirali model prilagođen kontekstu istraživanog problema, koristeći se teorijski utemeljenim i empirijskim potvrđenim mjernim ljestvicama. Konkretno empirijsko istraživanje koristit će prethodno spomenuti model u modificiranom i prilagođenom obliku. Anketni upitnik sastoji se od devet pitanja zatvorenog tipa, koja su podijeljena na tri cjeline. Prvi set pitanja čine općenita pitanja o ispitaniku (spol, dob, visina mjesečnih primanja, učestalost prisustvovanja na utakmicama te posjedovanje nekog modela pretplate HNK Hajduka). Drugu cjelinu čine pitanja pomoću kojih se ispitanik svrstava u jedan od unaprijed definiranih pet tipova navijača. Posljednja, treća cjelina pitanja odnosi se na namjeru ponovnog dolaska na utakmice, namjeru kupnje proizvoda HNK Hajduka, te namjeru kupnje proizvoda i usluga sponzora HNK Hajduka.

\subsection{Rezultati istraživanja}

Analizom podataka utvrđeno je da je anketnom upitniku pristupilo 148 muških osoba ( $52,3 \%$ ispitanika), te 135 ženskih osoba (47,7\% ispitanika). Što se tiče strukture ispitanika s obzirom na njihovu dob dvije dobne skupine su se najviše istaknule, a to su dobna skupina od 25-34 godine (51,2\% ispitanika, točnije njih 145) te dobna skupina od 18-24 godine (39,9\% ispitanika, točnije njih 113). Slijedi ih dobna skupina od 35-44 godine (6,7\% ispitanika, točnije njih 19), te posljednje dvije skupine, dobna skupina do 18 godina i dobna skupina od 45-54 godine, koje imaju jednake postotke (1,1\% ispitanika, točnije njih 3$)$. U daljnjoj analizi strukture ispitanika prikazane su dvostruke statističke tablice koje omogućuju istovremeni pregled ispitanika po dva kriterija. Prva dvostruka statistička tablica prezentira strukturu ispitanika na način da se u vezu dovodi spol ispitanika sa učestalosti prisustvovanja utakmicama HNK Hajduka. 
Tablica 1. Odnos ispitanika s obzirom na spol i učestalost prisustvovanja utakmicama HNK Hajduka

\begin{tabular}{|ll|l|l|l|}
\hline & & \multicolumn{2}{l|}{ Spol } & \\
\cline { 3 - 4 } & & M & Z & Total \\
\hline Koliko često u godini prisustvujete na & 0-1 put & 34 & 100 & 134 \\
utakmicama Hajduka? & 2-4 puta & 31 & 15 & 46 \\
& 5-6 puta & 11 & 8 & 19 \\
Total & 7 i više puta & 72 & 12 & 84 \\
\hline
\end{tabular}

Napomena: Grupiranje učestalosti prisustva se temelji na prvenstvenim utakmicama u kojim je Hajduk organizator, a čiji broj ovisi o sustavu natjecanja određene natjecateljske godine

Izvor: Istraživanje autora

Na temelju dane dvostruke tablice može se vidjeti da 100 ženskih ispitanica i 34 muška ispitanika prisustvuju 0-1 put godišnje utakmicama Hajduka, dok 72 muška ispitanika i 12 ženskih ispitanica prisustvuje 7 i više puta godišnje utakmicama Hajduka. Također je vidljivo da ukupno 31 muški ispitanik i 15 ženskih ispitanica prisustvuje utakmicama 2-4 puta godišnje, te da 11 muških ispitanika i 8 ženskih ispitanica prisustvuje utakmicama 5-6 puta godišnje. S obzirom da je nogomet kao sport dosta popularniji kod muške populacije može se reći da su dobiveni rezultati bili očekivani.

Tablica 2. Odnos ispitanika s obzirom na mjesečna primanja i učestalost prisustvovanja utakmicama HNK Hajduka

\begin{tabular}{|c|c|c|c|c|c|c|c|}
\hline & \multicolumn{5}{|c|}{ Mjesečna primanja (kn) } & \multirow[b]{2}{*}{ Total } \\
\hline & & $\begin{array}{l}\text { do } \\
2000,00\end{array}$ & $\begin{array}{c}2001,00 \\
- \\
4000,00\end{array}$ & $\begin{array}{c}4001,00 \\
- \\
6000,00\end{array}$ & $\begin{array}{c}6001,00 \\
- \\
8000,00\end{array}$ & $\begin{array}{c}\text { više od } \\
8000,00 \\
\end{array}$ & \\
\hline $\begin{array}{l}\text { Koliko često u } \\
\text { godini prisustvu- } \\
\text { jete na utakmi- } \\
\text { cama Hajduka? } \\
\text { Total }\end{array}$ & $\begin{array}{l}0-1 \text { put } \\
2-4 \text { puta } \\
5-6 \text { puta } \\
7 \text { i više puta }\end{array}$ & \begin{tabular}{|l|}
51 \\
20 \\
9 \\
24 \\
104
\end{tabular} & $\begin{array}{l}31 \\
8 \\
1 \\
20 \\
60\end{array}$ & $\begin{array}{l}34 \\
7 \\
6 \\
21 \\
68\end{array}$ & $\begin{array}{l}9 \\
6 \\
1 \\
9 \\
25\end{array}$ & $\begin{array}{l}9 \\
5 \\
2 \\
10 \\
26\end{array}$ & $\begin{array}{l}134 \\
46 \\
19 \\
84 \\
283 \\
\end{array}$ \\
\hline
\end{tabular}

Izvor: Istraživanje autora

U tablici 2 prikazan je odnos ispitanika s obzirom na mjesečna primanja i učestalost prisustvovanja utakmicama Hajduka. Od 134 ispitanika koji prisustvuju 
utakmicama 0-1 put godišnje njih 51 ima mjesečna primanja do 2000,00 kn, 31 ispitanik ima mjesečna primanja između 2001,00 i 4000,00 kn, 34 ispitanika ima mjesečna primanja između 4001,00 i 6000,00 kn, 9 ispitanika ima mjesečna primanja između 6001,00 i $8000,00 \mathrm{kn}$, te 9 ispitanika ima mjesečna primanja veća od 8000,00 kn. Nadalje od 46 ispitanika koji prisustvuju utakmicama 2-4 puta godišnje njih 20 ima mjesečna primanja do 2000,00 kn, 8 ispitanika ima mjesečna primanja između 2001,00 i 4000,00 kn, 7 ispitanika ima mjesečna primanja između 4001,00 i 6000,00 kn, 6 ispitanika ima mjesečna primanja između 6001,00 i $8000,00 \mathrm{kn}$, te 5 ispitanika ima mjesečna primanja veća od 8000,00 kn. U trećoj skupini ispitanika, onih koji prisustvuju utakmicama 4-6 puta godišnje, 9 ispitanika ima mjesečna primanja do 2000,00 kn, 1 ispitanik ima mjesečna primanja između 2001,00 i 4000,00 kn, 6 ispitanika ima mjesečna primanja između 4001,00 i $6000,00 \mathrm{kn}, 1$ ispitanik ima mjesečna primanja između 6001,00 i 8000,00 kn, te 2 ispitanika imaju mjesečna primanja veća od $8000,00 \mathrm{kn}$. Konačno u posljednjoj skupini ispitanika koji dolaze 7 i više puta godišnje njih 24 ima mjesečna primanja do 2000,00 kn, 20 ispitanika ima mjesečna primanja između 2001,00 i $4000,00 \mathrm{kn}, 21$ ispitanik ima mjesečna primanja između 4001,00 i 6000,00 kn, 9 ispitanika ima mjesečna primanja između 6001,00 i $8000,00 \mathrm{kn}$, te 10 ispitanika ima mjesečna primanja veća od $8000,00 \mathrm{kn}$. Zanimljivo je kako u sve četiri skupine najviše ima ispitanika koji imaju mjesečna primanja do 2000,00 kn. Međutim, također treba naglasiti kako 25 ispitanika (od njih 283) imaju primanja od 6001,00 do $8000,00 \mathrm{kn}$, te 26 ispitanika (od njih 283) imaju primanja viša od $8000,00 \mathrm{kn}$ te spadaju u kategoriju iznadprosječnih primanja s obzirom na prosječnu plaću u Hrvatskoj. S obzirom na navedeno može se zaključiti kako je moguće proširiti postojeću ponudu i modificirati ju prema različitim primanjima gledatelja.

Tablica 3. Odnos ispitanika s obzirom na mjesečna primanja i posjedovanje nekog od modela pretplate HNK Hajduka

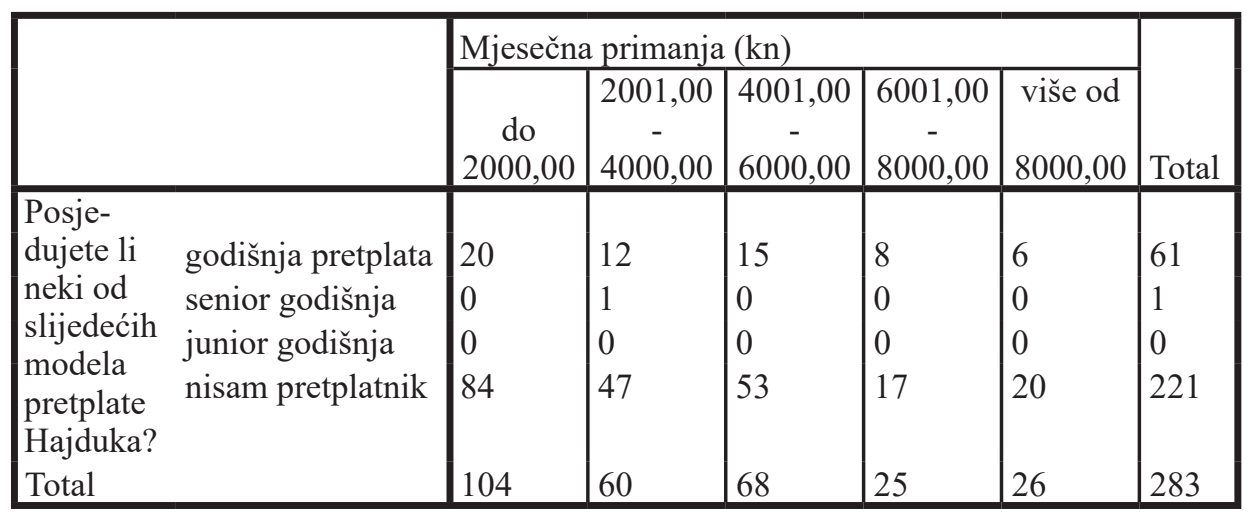

Izvor: Istraživanje autora 
Tablica 3 prikazuje odnos ispitanika s obzirom na mjesečna primanja i posjedovanje nekog od modela pretplate HNK Hajduka. Najveći broj ispitanika njih čak 221, iz svih razreda mjesečnih primanja, nisu pretplatnici Hajduka. Od 61 ispitanika koji posjeduju godišnju pretplatu njih 20 ima mjesečna primanja do 2000,00 kn, 12 ispitanika ima mjesečna primanja između 2001,00 i 4000,00 kn, 15 ispitanika ima mjesečna primanja između 4001,00 i 6000,00 kn, 8 ispitanika ima mjesečna primanja između 6001,00 i 8000,00 kn, te 6 ispitanika ima mjesečna primanja viša od $8000,00 \mathrm{kn}$. Senior godišnju pretplatu ima samo 1 ispitanik s mjesečnim primanjima između 2001,00 i 4000,00 kn. Junior godišnju pretplatu nema niti jedan ispitanik. Na temelju navedenih podataka vidljivo je kako mali dio ispitanika (njih oko 22\%) posjeduje neki od modela pretplate Hajduka. Ako se uzme u obzir da oko 53\% ispitanika prisustvuje na više utakmica godišnje, može se zaključiti kako bi u ovom području trebalo unaprijediti ili bolje upoznati korisnike sa ponudom pretplatničkih modela Hajduka i prednostima istih.

Tablica 4. Odnos ispitanika s obzirom na učestalost prisustvovanja utakmicama i posjedovanje nekog od modela pretplate HNK Hajduka

\begin{tabular}{|c|c|c|c|c|c|}
\hline & \multicolumn{5}{|c|}{$\begin{array}{c}\text { Koliko često prisustvujete } \\
\text { utakmicama Hajduka? }\end{array}$} \\
\hline & 1-1 put & $\begin{array}{c}2-4 \\
\text { puta }\end{array}$ & $\begin{array}{l}4-6 \\
\text { puta }\end{array}$ & $\begin{array}{c}\mathrm{i} \\
\text { više }\end{array}$ & Total \\
\hline $\begin{array}{ll}\text { Posjedujete li neki od slije- } & \\
\text { dećih modela pretplata Haj- } & \text { godišnja pretplata } \\
\text { duka? } & \text { senior godišnja } \\
& \text { junior godišnja } \\
& \text { nisam pretplatnik } \\
\text { Total } & \\
\end{array}$ & $\begin{array}{r}1 \\
0 \\
0 \\
133 \\
134\end{array}$ & $\begin{array}{r}3 \\
0 \\
0 \\
43 \\
46\end{array}$ & $\begin{array}{r}2 \\
0 \\
0 \\
17 \\
19\end{array}$ & $\begin{array}{r}55 \\
1 \\
0 \\
28 \\
84\end{array}$ & $\begin{array}{r}61 \\
1 \\
0 \\
221 \\
283\end{array}$ \\
\hline
\end{tabular}

Izvor: Istraživanje autora

Posljednja tablica prikazuje odnos ispitanika s obzirom na učestalost prisustvovanja utakmicama i posjedovanje nekog od modela pretplate. Najveći broj ispitanika njih čak 134, prisustvuju utakmicama 0-1 put godišnje, te njih 133 nisu pretplatnici HNK Hajduka dok jedan ispitanik posjeduje godišnju pretplatu. Od ispitanika koji prisustvuju utakmicama 2-4 puta godišnje (njih 46) 3 ispitanika posjeduju godišnju pretplatu, dok njih 43 nisu pretplatnici. Ukupno 19 ispitanika prisustvuje utakmicama 4-6 puta godišnje te u ovoj skupini samo 2 ispitanika posjeduju godišnju pretplatu dok 17 ispitanika nisu pretplatnici. Konačno ukupno 84 ispitanika prisustvuje utakmicama 7 i više puta. U ovoj skupini 55 ispitanika posjeduje godišnju pretplatu i jedan ispitanik posjeduje senior godišnju pretplatu, a njih čak 28 nisu pretplatnici Hajduka. 
Povežu li se posljednje tri tablice koje prikazuju rezultate vezane uz mjesečna primanja, učestalost prisustvovanja utakmicama i posjedovanje nekog od modela pretplata Hajduka vidljivi su mnogi propusti marketinškog odjela i prostor za unapređivanje ponude. Naime 46 ispitanika prisustvuje utakmicama 2-4 puta godišnje, 19 ispitanika prisustvuje utakmicama 4-6 puta godišnje i 84 ispitanika prisustvuje utakmicama 7 i više puta godišnje što ukupno čini 52,65\% svih ispitanika (njih 149 od 283). Kad se zbroje svi oblici pretplate koje posjeduju ispitanici dolazi se do rezultata kako 62 ispitanika (od njih 283) posjeduje neki od modela pretplate što čini 21,91\% ukupnih ispitanika. Također je vidljivo kako 119 ispitanika (od njih 283) spada u kategoriju prosječnih i iznadprosječnih primanja u RH te čini 40,05\% ukupnih ispitanika. Na temelju svega navedenog može se zaključiti kako postoji velik broj navijača koji učestalo prisustvuju utakmicama Hajduka te imaju prosječna ili iznadprosječna primanja, međutim više od pola tih navijača ne posjeduje neki od modela pretplata koji su u ponudi. Potrebno je bolje promovirati i oblikovati ponudu pretplata Hajduka na tržištu te upoznati navijače s prednostima istih, te tim putem bolje zadovoljiti postojeću potražnju.

Tablica 5. Segmentacija navijača

\begin{tabular}{|l|r|r|r|r|}
\hline & Frekvencija & $\%$ & Važeći \% & Kumulativno \\
\hline Fanatičan navijač & 27 & 9,5 & 9,5 & 9,5 \\
Predani navijač & 98 & 34,6 & 34,6 & 44,2 \\
Disfunkcionalni navijač & 5 & 1,8 & 1,8 & 45,9 \\
Predani lokalni navijač & 127 & 44,9 & 44,9 & 90,8 \\
Privremeni navijač & 26 & 9,2 & 9,2 & 100,0 \\
Total & 283 & 100,0 & 100,0 & \\
\hline
\end{tabular}

Izvor: Istraživanje autora

Slijedi analiza navijača kroz pet različitih segmenata povezana s dobivenim rezultatima istraživanja. „Fanatičan navijač“ (engl. The fanatical fan) bi se mogao okarakterizirati kao vrlo posvećen klubu za kojeg navija, te nije vremenski ili geografski ograničen kao neki od ostalih tipova navijača. Njima je identifikacija vrlo jaka i bitna, oni su strastveni navijači koji su snažno povezani sa svojim omiljenim klubom. Za njih sport predstavlja vrlo značajan aspekt života, koji slijedi odmah iza bitnih aspekata kao što su obitelj, posao i religija. Neke od njihovih karakteristika su te da prisustvuju utakmicama obilježeni bojama i simbolima kluba, obučeni su u kostime te ostaju uz svoj klub bez obzira na rezultat (Agas i dr., 2012., 113). Na temelju tablice frekvencija vidljivo je kako 9,5\% ukupnih ispitanika (točnije njih 27) spada u ovu skupinu navijača. Ova skupina je treća po 
veličini s obzirom na broj ispitanika koji u nju spadaju. Može se zaključiti kako ovaj određeni broj ispitanika voli kupovati navijačke proizvode, posjeduje velik broj istih, te voli nositi dresove i druga timska obilježja na utakmicama Hajduka.

„Predani navijač“ (engl. The devoted fan) također nije vremenski niti geografski ograničen, on svoj omiljeni klub doživljava kao dio sebe. Ima vrlo visoku razinu identifikacije, razvija zaštitnički stav prema klubu koji ga sprječava na emocionalnoj razini da prihvati eventualni gubitak utakmice ili neuspjeh. Sklon je pripisivanju pozitivnih atributa svome omiljenom klubu dok sve negativne dodjeljuje protivničkom klubu. Vrlo intenzivno i osobno doživljava radost i zadovoljstvo zbog pobijede njegovog kluba, međutim istim intenzitetom doživljava bol i razočaranje zbog gubitka utakmice. Ovaj tip navijača ostaje vjeran svom klubu i u dobrim i u lošim sezonama (Agas i dr., 2012., 113). Druga skupina po veličini s obzirom na broj ispitanika, ukupno 98 ispitanika (točnije njih 34,6\%), te se za njih može kazati kako imaju visoku razinu povezanosti s Hajdukom te vrlo emotivno i intenzivno doživljavaju njegove poraze i pobijede. Fanatični navijači i predani navijači su dugoročno dobri i vjerni kupci proizvoda i usluga Hajduka. Ako se uzmu u obzir obilježja i karakteristike ove dvije skupine vidljivo je kako bi se postojeća ponuda mogla prilagoditi svrsishodnom nagrađivanju vjernosti s ciljem većeg zadovoljstva privrženih korisnika.

„Disfunkcionalni navijač“ (engl. The dysfunctional fan) spada u vrlo problematičnu skupinu navijača. Nije rijetka pojava za ovu vrstu navijača da daje prioritet svome omiljenom klubu ili sportu, zanemarujući u tom slučaju obitelj, posao i prijatelje. Za razliku od „predanog navijača“ koji ima pozitivan navijački stav i željan je dobre sportske zabave, ,disfunkcionalni navijač“ ima antisocijalni stav, nasilno i devijantno ponašanje koje vrijeđa principe sportskih i društvenih događanja. Oni se vrlo snažno poistovjećuju s predmetom svog fanatizma te doživljavaju emocije kao što su tjeskoba, ljutnja i bol u tako ekstremnom stupnju da često gube kontrolu nad samim sobom. Najtipičniji predstavnici ove kategorije su engleski nogometni navijači, zloglasni „huligani“ (Agas i dr., 2012., 113-114). Ovu skupinu navijača čini $1,8 \%$ ukupnih ispitanika, točnije njih 5. Ovakav rezultat je vrlo poželjan s obzirom na karakteristike „disfunkcionalnih navijača“ i eventualne probleme koji proizlaze iz njihovog ponašanja.

„Lokalni navijač“ (engl. The local fan) je najviše ograničen geografski, te se u ovoj skupini navijača mogu izdvojiti dvije podskupine: „Privremeni lokalni navijač“ i „Predani lokalni navijač“. Navijačka priklonjenost lokalnog navijača određenom klubu služi njegovoj samo identifikaciji i proizlazi iz identifikacije s geografskim područjem. On podržava lokalni tim jer smatra da treba pokazati određeni stupanj odanosti prema istome na temelju grada rođenja ili prebivališta. Može se reći da osjećaju određenu obavezu prema lokalnom sportskom timu. 
„Predani lokalni navijač“ vjeran je, ima visoku razinu identifikacije i snažan zaštitnički stav prema omiljenom lokalnom timu. „Privremeni lokalni navijač“ mijenja svoju naklonost prema lokalnom timu u slučaju preseljenja u drugi grad ili odlaska njegovog omiljenog igrača u drugi klub, te se njegova identifikacija može okarakterizirati kao prolazna (Agas i dr., 2012., 114). Na temelju tablice frekvencija vidljivo je kako najveći postotak ispitanika 44,9\% (točnije njih 127) spada u skupinu ,predani lokalni navijač“ dok niti jedan ispitanik ne spada u skupinu ,privremeni lokalni navijač“. Može se zaključiti da 44,9\% ispitanika osjeća snažnu povezanost i visoku razinu identifikacije s lokalnim klubom koja preseljenjem u neki drugi grad ne bi bila narušena. Ova skupina navijača vrlo je bitna za dugoročno poslovanje HNK Hajduka te za kupovinu njihovih usluga i proizvoda. Većina pripadnika Torcide, navijača Hajduka, spada upravo u skupinu ,predani lokalni navijači“. Torcida uvijek vjerno prati momčad Hajduka na svim gostovanjima, kako onim europskim, tako i onim van europskim te je već legendarna priča kako Hajduk nigdje nije gostovao bez podrške svojih navijača. Osim u Hrvatskoj, društava prijatelja i navijača Hajduka ima na svim naseljenim kontinentima zahvaljujući iseljenicima iz Hrvatske (većinom iz Dalmacije).

„Privremeni navijač“ (engl. The temporary fan) svoju odanost određenom klubu ne koristi za samo identifikaciju. Njegova zainteresiranost za sport i navijanje okarakterizirana je kao situacijska te je vremenski ograničena. „Privremeni navijač“ je sportski potrošač samo za određeno vrijeme čije trajanje može varirati od nekoliko sati do nekoliko godina. On je navijač samo za vremenski ograničen događaj ili period u kojem je njegov omiljeni igrač dio određenog tima. Predanost „privremenog navijača“ je kalkulativna što znači da će on biti navijač dok god prednosti navijanja nadilaze troškove. U periodu kada njegov klub pobjeđuje on je odan, vjeran navijač koji se poistovjećuje sa pobjedom svog kluba govoreći „Mi smo dobili!““. U slučaju gubitka utakmice on postaje nezainteresiran, odvaja se od svog tima govoreći „Oni su izgubili!““(Agas i dr., 2012., 112-113). Konačno u posljednju skupinu navijača spada $9,2 \%$ ispitanika (točnije njih 26). Segment „privremeni navijač“ donosi kratkoročnu zaradu te bi se trebale osmisliti bolje promocije i ponude kod nekih bitnijih utakmica Hajduka kako bi se privuklo što više takvih navijača s ciljem ostvarenja većih profita.

Nakon podijele ispitanika na segmente slijede tri dvostruke tablice u kojima će u odnos biti stavljeni navedeni segmenti te mjesečna primanja, učestalost prisustvovanja na utakmicama i modeli pretplate. 
6. Odnos ispitanika s obzirom na tip navijača i mjesečna primanja

\begin{tabular}{|c|c|c|c|c|c|c|c|}
\hline & \multicolumn{5}{|c|}{ Mjesečna primanja (kn) } & \multirow[t]{2}{*}{ Total } \\
\hline & & $\begin{array}{c}\text { do } \\
2000,00\end{array}$ & $\begin{array}{r}2001,00 \\
-4000,00\end{array}$ & $\begin{array}{r}4001,00 \\
-6000,00\end{array}$ & $\begin{array}{r}6001,00 \\
-8000,00\end{array}$ & $\begin{array}{c}\text { više od } \\
8000,00\end{array}$ & \\
\hline & Fanatičan & 5 & 10 & 8 & 1 & 3 & 27 \\
\hline gmen- & Predani & 41 & 17 & 22 & 7 & 11 & 98 \\
\hline tacija & Disfunkcionalni & 0 & 1 & 1 & 2 & 1 & 5 \\
\hline navijača & Predani lokalni & 47 & 24 & 31 & 14 & 11 & 127 \\
\hline & Privremeni & 11 & 8 & 6 & 1 & 0 & 26 \\
\hline Total & & 104 & 60 & 68 & 25 & 26 & 283 \\
\hline
\end{tabular}

Izvor: Istraživanje autora

Iz tablice 6 može se vidjeti kako kod skupine ,predani lokalni navijač“ (njih 127) ukupno 47 ispitanika ima mjesečna primanja do 2000,00 kn, 31 ispitanik ima primanja od 4001,00 do 6000,00 kn, njih 24 ima primanja od 2001,00 do $4000,00 \mathrm{kn}, 14$ ispitanika ima primanja od 6001,00 do $8000,00 \mathrm{kn}$ te 11 ispitanika ima primanja viša od 8000,00 kn. Kod skupine ,predani navijač“ (njih 98) najviše je ispitanika sa primanjima do 2000,00 kn (njih 41), slijede ih ispitanici s primanjima od 4001,00 do 6000,00 kn (njih 22), zatim oni s mjesečnim primanjima od 2001,00 do 4000,00 kn (njih 17), te ispitanici s primanjima većim od $8000,00 \mathrm{kn}$ (njih 11) i ispitanici s primanjima od 6001,00 do 8000,00 kn (njih 7). U skupini „fanatični navijač“ (njih 27) 10 ispitanika ima primanja od 2001,00 do $4000,00 \mathrm{kn}, 8$ ispitanika ima primanja od 4001,00 do 6000,00 kn, 5 ispitanika ima primanja do $2000,00 \mathrm{kn}, 3$ ispitanika ima primanja veća od 8000,00 kn i 1 ispitanik ima primanja od 6001,00 do $8000,00 \mathrm{kn}$. Što se tiče skupine,,privremeni navijač“" (njih 26) najviše ispitanika (njih 11) ima primanja do 2000,00 kn, zatim ispitanici s primanjima od 2001,00 do 4000,00 kn (njih 8), potom ispitanici s primanjima od 4001,00 do 6000,00 kn (njih 6) i 1 ispitanik s primanjima od 6001,00 do 8000,00 kn. U posljednjoj skupini, ,disfunkcionalni navijač“ (njih 5), imaju 2 ispitanika s primanjima od 6001,00 do $8000,00 \mathrm{kn}$ te po 1 ispitanik s mjesečnim primanjima od 2001,00 do 4000,00 kn, 4001,00 do 6000,00 kn i većim od $8000,00 \mathrm{kn}$. Vidljivo je da u većini segmenata najviše ima ispitanika s mjesečnim primanjima do 2000,00 kn (njih 104), slijede ih ispitanici s primanjima od 4001,00 do 6000,00 kn (njih 68), ispitanici s primanjima od 2001,00 do 4000,00 kn (njih 60), ispitanici s primanjima većim od 8000,00kn (njih 26) te ispitanici s primanjima od 6001,00 do $8000,00 \mathrm{kn}$ (njih 25). Uzme li se u obzir da prosječna plaća u Hrvatskoj iznosi oko 5500,00 kn rezultati se mogu grupirati u tri skupine. Prva skupina bi bili oni navijači s ispodprosječnim primanjima u koju spada ukupno 164 ispitanika, njih $104 \mathrm{~s}$ primanjima do 2000,00 kn i njih $60 \mathrm{~s}$ primanjima od 2001,00 do 4000,00 kn. U drugu skupinu spadaju navijači s prosječnim primanjima njih 68 (primanja od 4001,00 do 6000,00 kn). Treća skupina obuhvaća 
ukupno 51 navijača s iznadprosječnim primanjima, $25 \mathrm{~s}$ primanjima od 6001,00 do $8000,00 \mathrm{kn}$ i $26 \mathrm{~s}$ primanjima višim od $8000,00 \mathrm{kn}$.

Tablica 7. Odnos ispitanika s obzirom na tip navijača i model pretplate

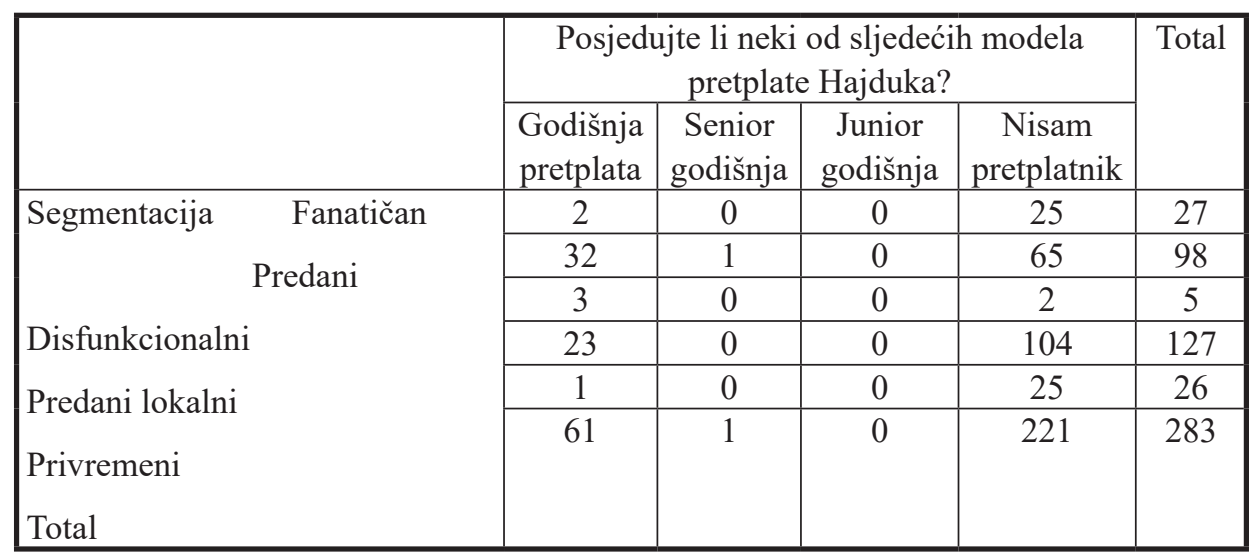

Izvor: Istraživanje autora

U tablici 7 prikazan je odnos ispitanika s obzirom na tip navijača i model pretplate. Iz priloženog se vidi kako kod skupine „predani lokalni navijač“ (njih 127) 104 ispitanika nisu pretplatnici Hajduka, dok 23 ispitanika imaju godišnju pretplatu. Kod skupine ,predani navijač“ (njih 98) najviše je ispitanika koji nisu pretplatnici (njih 65), zatim ispitanika koji imaju godišnju pretplatu (njih 32) te jedan ispitanik koji ima senior godišnju pretplatu. U skupini „fanatični navijač“ (njih 27) samo dvoje ispitanika ima godišnju pretplatu, a čak njih 25 nisu pretplatnici Hajduka. Što se tiče skupine ,privremeni navijač“ (njih 26) očekivano gotovo svi ispitanici nisu pretplatnici (njih 25), dok jedan ispitanik ima godišnju pretplatu. U posljednjoj skupini, „disfunkcionalni navijač“ (njih 5), ima tri ispitanika koji imaju godišnju pretplatu te dva ispitanika koji nisu pretplatnici. Vidljivo je da u većini segmenata najviše ima ispitanika koji nisu pretplatnici HNK Hajduka (njih 221), slijede ih ispitanici koji imaju godišnju pretplatu (njih 61) te senior godišnju pretplatu (1 ispitanik).

Glavna hipoteza istraživanja postavljena je s ciljem da se istraži postoji li statistički značajna razlika među segmentima navijača u namjeri ponovne kupnje. U svrhu lakšeg i detaljnijeg testiranja glavne hipoteze postavljene su tri pomoćne hipoteze. Prva pomoćna hipoteza stavlja u odnos segmentaciju navijača i namjeru ponovnog dolaska na utakmice, druga stavlja u odnos segmentaciju navijača i namjeru ponovne kupnje proizvoda Hajduka, te treća pomoćna hipoteza stavlja u odnos segmentaciju navijača i namjeru kupnje proizvoda i usluga sponzora Hajduka. Za testiranje pomoćnih hipoteza korišten je Kruskal Wallis test, budući 
je riječ o redoslijednoj mjernoj skali s pet nezavisnih uzoraka, te su na temelju odgovora na postavljena pitanja korištenih ljestvica doneseni odgovarajući zaključci. Grupirajuća varijabla za ovaj test bila je „segmenti navijača“.

Tablica 8. Kruskal Wallis test - testiranje razlike među segmentima navijača u namjeri ponovnog dolaska na utakmice HNK Hajduka

\begin{tabular}{|l|c|c|c|}
\hline & \multicolumn{3}{|c|}{ Koliko je vjerojatno da će(te)... } \\
\cline { 2 - 4 } & $\begin{array}{c}\text { prisustvovati } \\
\text { idućim uta- } \\
\text { kmicama HNK } \\
\text { Hajduka? }\end{array}$ & $\begin{array}{c}\text { odlazak na utakmicu Hajduka } \\
\text { biti Vaš prvi izbor prilikom } \\
\text { odabira nekog sportskog do- } \\
\text { gađaja u budućnosti? }\end{array}$ & $\begin{array}{c}\text { prisustvovati } \\
\text { većem broju uta- } \\
\text { kmica Hajduka u } \\
\text { budućnosti? }\end{array}$ \\
\hline Chi-Square & 59,071 & 63,935 & 65,752 \\
Df & 4 & 4 & 4 \\
Asymp. Sig. &, 000 &, 000 &, 000 \\
\hline & & & \\
\hline
\end{tabular}

Izvor: Istraživanje autora

Prilikom testiranja prve pomoćne hipoteze utvrđeno je kako postoji statistički značajna razlika među segmentima navijača u namjeri ponovnog dolaska na utakmicu. Do ovog zaključka došlo se pregledom rezultata Kruskal Wallis testa koji se koristio prilikom analize odgovora na tri potpitanja vezana uz prvu pomoćnu hipotezu. Empirijska signifikantnost u sva tri testa približno je jednaka nuli (1. test: $x^{2}=59,071 ; p<0.001 ; 2$. test: $x^{2}=63,935 ; p<0.001 ; 3$. test: $x^{2}=65,752$; $\mathrm{p}<0.001)$ na temelju čega se zaključuje kako postoji statistički značajna razlika među segmentima navijača u namjeri prisustvovanja idućim utakmicama Hajduka, vjerojatnosti odlaska na utakmicu Hajduka kao prvog izbora prilikom odabira odlaska na neki sportski događaj u budućnosti te vjerojatnosti njihovog prisustvovanja većem broju utakmica Hajduka u budućnosti.

Tablica 9. Kruskal Wallis test- testiranje razlike među segmentima navijača i vjerojatnosti kupovine proizvoda HNK Hajduka na idućim utakmicama

\begin{tabular}{|c|c|c|c|}
\hline \multirow{2}{*}{} & \multicolumn{3}{|c|}{ Koliko je vjerojatno da će(te)... } \\
\cline { 2 - 4 } & $\begin{array}{c}\text { na idućim utakmica- } \\
\text { ma kupiti proizvod } \\
\text { Hajduka? }\end{array}$ & $\begin{array}{c}\text { proizvodi Hajduka biti } \\
\text { Vaš prvi izbor prilikom } \\
\text { odabira navijačkih proi- } \\
\text { zvoda u budućnosti? }\end{array}$ & $\begin{array}{c}\text { kupiti veći broj pro- } \\
\text { izvoda Hajduka u } \\
\text { budućnosti? }\end{array}$ \\
\hline Chi-Square & 55,627 & 50,159 & 59,651 \\
Df & 4 & 4 & 4 \\
Asymp. Sig. &, 000 &, 000 &, 000 \\
\hline & & & \\
\hline
\end{tabular}

Izvor: Istraživanje autora 
Kod testiranja druge pomoćne hipoteze, u tablici 9 je vidljivo kako je empirijska signifikantnost kod sva tri pitanja približno jednaka nuli (1. test: $\mathrm{x} 2=55,627$; $\mathrm{p}<0.001 ; 2$. test: $\mathrm{x} 2=50,159 ; \mathrm{p}<0.001 ; 3$. test: $\mathrm{x} 2=59,651 ; \mathrm{p}<0.001)$ što upućuje na to kako postoji značajna razlika među segmentima navijača u namjeri kupnje proizvoda Hajduka na idućim utakmicama, vjerojatnosti izbora proizvoda Hajduka kao prvog izbora prilikom odabira navijačkih proizvoda u budućnosti te vjerojatnosti kupovine većeg broja proizvoda Hajduka u budućnosti. Temeljem ovih rezultata prihvaćena je i druga pomoćna hipoteza te je utvrđeno kako postoji statistički značajna razlika među segmentima navijača u namjeri ponovne kupnje proizvoda HNK Hajduka.

Tablica 10. Kruskal Wallis test- testiranje razlike među segmentima navijača i vjerojatnosti kupovine proizvoda od nekog sponzora HNK Hajduka

\begin{tabular}{|c|c|c|c|}
\hline \multirow{2}{*}{} & \multicolumn{3}{|c|}{ Koliko je vjerojatno da će(te)... } \\
\cline { 2 - 4 } & $\begin{array}{c}\text { prilikom iduće kupovi- } \\
\text { ne kupiti proizvod od } \\
\text { nekog sponzora HNK } \\
\text { Hajduka (Tommy, OTP, } \\
\text { Croatia osiguranje, Kar- } \\
\text { lovačko)? }\end{array}$ & $\begin{array}{c}\text { proizvodi sponzora HNK } \\
\text { Hajduka biti Vaš prvi iz- } \\
\text { bor u odnosu na iste proi- } \\
\text { zvode drugih proizvođača } \\
\text { u budućnosti? }\end{array}$ & $\begin{array}{c}\text { kupiti veći } \\
\text { broj proizvoda } \\
\text { sponzora HNK } \\
\text { Hajduka u bu- } \\
\text { dućnosti? }\end{array}$ \\
\hline $\begin{array}{c}\text { Chi-Square } \\
\text { Df }\end{array}$ & 41,924 & 63,946 & 64,619 \\
Asymp. Sig. & 4 & 4 & 4 \\
&, 000 &, 000 &, 000 \\
\hline
\end{tabular}

Izvor: Istraživanje autora

Treća pomoćna hipoteza također sadrži tri potpitanja te je testirana kao i prethodne dvije hipoteze. Empirijska signifikantnost u sva tri testa približno je jednaka nuli (1. test: $x 2=41,924 ; \mathrm{p}<0.001 ; 2$. test: $\mathrm{x} 2=63,946 ; \mathrm{p}<0.001 ; 3$. test: $\mathrm{x} 2=64,619$; $\mathrm{p}<0.001)$ na temelju čega se zaključuje kako postoji statistički značajna razlika među segmentima navijača i vjerojatnosti kupovine proizvoda nekog od sponzora Hajduka, vjerojatnosti odabira proizvoda sponzora Hajduka kao prvog izbora u odnosu na iste proizvode drugih proizvođača u budućnosti te vjerojatnosti kupovine većeg broja proizvoda sponzora Hajduka u budućnosti. Temeljem ovih rezultata prihvaćena je i treća pomoćna hipoteza te je utvrđeno kako postoji razlika među segmentima navijača u namjeri ponovne kupnje proizvoda i usluga sponzora HNK Hajduka.

Na temelju provedenih testiranja i dobivenih rezultata može se reći da je temeljna hipoteza istraživanja kako postoji razlika među segmentima navijača u namjeri ponovne kupnje potvrđena. Temeljnoj hipotezi dodane su tri pomoćne hipoteze kako bi se što bolje ispitale razlike među pojedinim segmentima navijača u 
namjeri ponovnog dolaska na utakmice Hajduka, namjeri kupovine proizvoda Hajduka i namjeri kupovine proizvoda sponzora Hajduka. Iz navedenih rezultata vidljivo je da se navijači Hajduka mogu grupirati u pet različitih segmenata $s$ obzirom na njihove karakteristike, te se na osnovi istih može predvidjeti namjera ponovne kupnje. HNK Hajduk bi trebao svoju postojeću ponudu proizvoda i usluga prilagoditi i oblikovati prema karakteristikama navedenih segmenata $\mathrm{s}$ ciljem povećanja broja posjeta na utakmicama, kupovine svojih proizvoda i usluga, te proizvoda i usluga svojih sponzora. U konačnici ovo testiranje bi Hajduku moglo pomoći da bolje zadovolji postojeću potražnju za svojim proizvodima i uslugama.

\subsection{Ograničenja istraživanja}

Iako rezultati istraživanja jasno ukazuju na prirodu veze ispitivanih koncepata ipak treba imati na umu i postojeća ograničenja ovog istraživanja. Prvo ograničenje odnosi se na uzorak istraživanja. Istraživanje je provedeno na 283 ispitanika te ako se uzme u obzir opseg i veličina baze navijača HNK Hajduka, veličina uzorka korištena u ovom slučaju nije zadovoljavajuća da bi se mogli izvesti konačni zaključci. Kod raspodjele ispitanika u pojedine segmente niti jedan nije spadao u segment ,privremeni lokalni navijač“. Ovakvom rezultatu doprinosi činjenica kako nije rađena klasterizacija ispitanika niti faktorska analiza karakteristika unaprijed definiranih segmenata navijača. Međutim može se reći da su dobiveni rezultati prikladni za donošenje indikativnih zaključaka dok bi za stvaranje potpune slike bilo potrebno provesti istraživanje na većem uzorku uz recentnije statističke analize. Ograničenje istraživanja predstavljaju i pojedini dijelovi mjernog instrumenta u kojima je korištena redoslijedna skala mjerenja te se odgovori temelje na subjektivnoj procjeni ispitanika. Iako je anketa anonimna ne smije se zanemariti utjecaj društvene poželjnosti odgovora i sama pristranost ispitanika u davanju odgovora.

Nadalje, ograničenje istraživanja vezuje se i uz nedostatak prethodnih istraživanja na prostoru Hrvatske s kojima bi se rezultati provedenog istraživanja mogli uspoređivati. Prilikom sastavljanja upitnika korištena su istraživanja koja su provođena u Velikoj Britaniji i drugim europskim zemljama koje su u odnosu na nas, u kulturološkom i razvojnom smislu različite. Iz tog razloga bile su potrebne određene prilagodbe anketnog upitnika, a otežana je i interpretacija rezultata istraživanja zbog nemogućnosti usporedbe rezultata i izvođenja zaključaka temeljem njihove komparacije. 


\section{ZAKLJUČAK}

Istraživanje utjecaja segmentacije navijača na namjeru ponovne kupnje je ispitano većim brojem stranih studija koje su pritom dokazale kako je ispitivana veza pozitivna te ju je nužno implementirati u marketinšku teoriju, kao bitan element pri strateškom odlučivanju. Stoga ni ne čudi sve veća potreba stranih nogometnih klubova, samim time i domaćih, za boljim razumijevanjem i segmentacijom navijača budući da glavni izvor prihoda nogometnih klubova predstavljaju upravo financijska sredstva dobivena od prodaje ulaznica. Uočavanjem važnosti utjecaja dobre segmentacije navijača na namjeru ponovne kupnje proizvoda i usluga HNK Hajduka i njegovih sponzora, otvoren je i novi prostor razumijevanju upravljačkih odluka. Nadalje, provedeno istraživanje je pokazalo kako je dobra segmentacija navijača značajan i determinirajući čimbenik u namjeri ponovne kupnje. Iz spomenutog proizlaze implikacije za stručnjake iz područja sportskog marketinga koji bi trebali bolje razumjeti važnost različitih karakteristika pojedinih segmenata navijača te njihove namjere ponovne kupnje koje značajno utječu na poslovne rezultate kluba.

Rezultati testiranja pomoćnih hipoteza postavljenog modela su potvrdili kako postoji statistički značajna razlika među segmentima navijača u namjeri ponovnog dolaska na utakmicu, namjeri kupnje proizvoda kluba kao i namjeri kupnje proizvoda i usluga sponzora kluba. Temeljem svega navedenog potvrđena je temeljna hipoteza istraživanja kako postoji statistički značajna razlika među segmentima navijača u namjeri ponovne kupnje na primjeru HNK Hajduka. Prethodno u radu je istaknuto kako su navijači podijeljeni u pet segmenata. Prilikom analize odgovora ispitanika utvrđeno je kako u ovom konkretnom uzorku niti jedan ispitanik ne spada u podsegment ,privremeni lokalni navijač“ koji je dio segmenta „lokalni navijač“. Do ovakvih rezultata se došlo zbog prethodno navedenih ograničenja uzorka istraživanja. Unatoč svemu vidljivo je kako ipak postoji pet segmenata navijača koji se razlikuju po svojim karakteristikama i preferencijama proizvoda i usluga Hajduka i njegovih sponzora. Upravo te karakteristike pojedinih segmenata su ključne za buduće marketinške odluke vezane uz unapređenje usluga i proizvoda Hajduka. S ciljem povećanja vjernosti svojih kupaca Hajduk bi trebao prilagoditi i oblikovati svoju ponudu navedenim segmentima. Sustav nagrađivanja vjernosti pokazao se kao vrlo dobar u mnogim drugim područjima te bi se mogao iskoristiti i u ovom slučaju kako bi najvjerniji navijači imali posebne pogodnosti i nagrade kao najprofitabilniji kupci proizvoda i usluga. Dodatni marketinški napori bi trebali biti usmjereni na određene zajedničke akcije kluba i njegovih sponzora za vrijeme, prije i poslije sportske priredbe kako bi dodatno zadovoljili želje i potrebe navijača, ali i ostalih uključenih dionika. 
Rezultati deskriptivne statistike su ukazali na nekoliko nedostataka te bi se na temelju istih trebalo poraditi na poboljšanju kvalitete usluge i unaprjeđivanju njenih elemenata. Pregledom tablica s rezultatima vidljivo je kako 19 ispitanika (od njih 283) prisustvuje utakmicama Hajduka 5-6 puta godišnje te 84 ispitanika (od njih 283) prisustvuje utakmicama 7 i više puta godišnje što zajedno čini 36,39\% ukupnih ispitanika, međutim 78,09\% ispitanika (njih 221 od 283) nisu pretplatnici Hajduka. Postoje razne opcije kako privući nove pretplatnike i zadržati postojeće. Glavnina marketinških napora bi trebala biti usmjerena prema segmentu ,predani lokalni navijači“ koji predstavljaju najvjernije posjetitelje te kupce kako klupskih tako i sponzorskih proizvoda i usluga. Pritom ne treba zanemariti dva bitna segmenta navijača, ,fanatični navijač“ i ,predani navijač“, te njihovu sklonost kupovanju navijačkih (i/ili klupskih) proizvoda. Neke od opcija bi mogle biti osmišljavanje novih paketa za segment „lokalnih navijača“ (obiteljska pretplata; zlatna pretplata s dodatnim pogodnostima (primjerice zagarantirano parkirno mjesto u krugu stadiona)) $\mathrm{i} / \mathrm{ili}$ akcijske ponude pretplata kako bi se nagradila vjernost istih. Promoviranje posebnih pogodnosti za određene skupine mogućih pretplatnika (upoznavanje djece s igračima, potpisani dres Hajduka za „predane navijače“, memorabilije za „fanatične navijače“), kao i vezane ponude određenih pogodnosti kod sponzora kluba. Svaka od ovih opcija ima isti cilj, a to je povećanje zadovoljstva korisnika usluga Hajduka i povećanje profita, međutim ponude bi se trebale očito adekvatnije osmišljavati i efikasnije promovirati kako bi se mogući korisnici bolje informirali o detaljima i pogodnostima istih. Nadalje, iz rezultata je vidljivo kako 51 ispitanik (od njih 283) ima iznadprosječna primanja s obzirom na prosječnu plaću u Hrvatskoj. Trebalo bi ispitati preferencije ovih navijača te oblikovati ponude poput onih na najvećim europskim stadionima koje bi uključivale pristup ekskluzivnim područjima stadiona (engl. Corporate hospitality boxes; restaurant boxes; cafe boxes...) odakle bi se pratila utakmica, družilo s poslovnim partnerima, uživalo u wellness tretmanima i sl. To je skupina koja bi vjerojatno bila voljna platiti veću cijenu za bolju uslugu te postati dugoročno vjerniji kupac. Buduća istraživanja bi trebala pružiti dodatne empirijske dokaze valjanosti predloženog modela istraživanja. Iz tog razloga se predlaže istraživanje na većem uzorku navijača Hajduka ili pak na većem broju klubova s područja RH kako bi se identificirale sličnosti i razlike u rezultatima istraživanja. Konačno, u budućim istraživanjima moglo bi se uključiti dodatne varijable u model kako bi se poboljšala njegova moć pojašnjavanja uzročno-posljedičnih odnosa među promatranim konstruktima. 


\section{LITERATURA}

\section{Knjige:}

1. Bartoluci, M., (2003.), Ekonomika i menadžment sporta, GRAFEX, Zagreb

2. Bartoluci, M., Škorić, S., (2009.), Menadžment sportskog i nautičkog turizma, Veleučilište u Karlovcu, Karlovac

3. Fischer, K.D., (2019.), Give the Fans What They Want: A Market Segmentation Approach to Sport Fans' Social Media Usage, Dissertation, University of Northern Colorado

4. Kesić, T., (2006.), Ponašanje potrošača, Opinio d.o.o., Zagreb

5. Kościółek, S., Nessel, K., (2019.), Market segmentation of football fans in Poland. Globalized Sport Management in Diverse Cultural Contexts, editor Zhang, J.J: and Pitts, B.G., Routledge, New York, USA.

6. Kotler, P., (2001.), Marketing Management Millenium Edition, Pearson Custom Publishing, New Yersey, Tenth edition

7. Mullin B.J.; Hardy S.; Sutton W.A., (2000.), Sport Marketing, Human Kinetics Book, IL, USA

8. Novak, I., (2006.), Sportski marketing i industrija sporta, Maling, Zagreb

9. Oliver, R. L., (1997.) Satisfaction: A Behavioural Perspective on the Consumer, New York: McGraw Hill

10. Previšić, J., Ozretić-Došen, Đ., (2007.), Osnove marketinga, ADVERTA, Zagreb

11. Wann, D., Melnick, M., Russell, G., Pease, D., (2001.), Sport fans: The psychology and social impact of spectators, New York: Rontledge

12. Westerbeek, H., Smith, A., (2003.), Sport business in the global marketplace, New York: Palgrave Macmillan

\section{Znanstveni članci:}

1. Agas, K., Georgakarakou, C., Mylonakis, J., Arsenos, P., (2012.), Traveling Abroad Internal and External Motives Toward Different Sports Fan Types, International Journal of Business and Management, Vol. 7, No. 3, str. 111-126

2. Bolton, R. N., Kannan, P. K., Bramlett, M. D., (2000.), Implications of loyalty program membership and service experience for customer retention and value, Journal of the academy of marketing, Vol. 28, No. 1, str. 95-108

3. Boonlertvanich, K., (2001.), A conceptual model for repurchase intentions in the automobile service industry: the role of switching barriers in satisfaction 
repurchase intentions relationship, International journal of business research, Vol. 9, No. 6, str. 1-18

4. Cronin, J. J. Jr., Brady, M. K., Hult, G. T. M., (2000.), Assessing the effects of quality, value, and customer satisfaction on consumer behavioral intentions in service environments, Journal of Retailing, Vol. 76, No. 2., str. 193-218

5. Hume, M., Mort, G.S., (2010.), The consequence of appraisal emotion, service quality, perceived value and customer satisfaction on repurchase intent in the performing arts, Journal of Services Marketing, Vol. 24, No. 2, str. $170-182$

6. Kim, J.-W., Hong, H.-G., Kim, E.-J., Kim, S.-M., (2011.), Effects of fit with CSR activities and consumption value on corporate image and repurchase intention, International Journal of business strategy, Vol. 11, No. 1, str. 35-46

7. Kim, Y.H., Duncan, J.L. and Jai, T.-M., (2016.), Segmenting the collegiate football game spectator: a cluster analysis approach, Sport, Business and Management, Vol. 6 No. 1, str. 76-96

8. Kitchathorn, P., (2009.), Factor Influencing Customer Repurchase Intention: An Investigation of Switching Barriers that Influence the Relationship between Satisfaction and Repurchase Intention in the Low Cost airlines Industry in Thailand, School of Business Administration (DBA), Unpublished doctoral thesis of University of South Australia, Australia, str. 1-22

9. Meir, R., (2000.), Fan reaction to the match day experience: A case study in English professional rugby league, Sport Marketing Quarterly, Vol. 9., No. 1., str. 34-42

10. Olaru, D., Petersen, N., Purchase, S., (2008.), From customer value to repurchase intentions and recommendations, Journal of Business and Industrial Marketing, Vol. 23, No. 8, str. 554-565

11. Redden, J., Steiner, C., (2000.), Fanatical consumers: Toward a framework for research, Journal of Consumer Markting, Vol. 17., No 4., str. 322-337

12. Stewart, B., Smith, A.C.T., Nicholson, M., (2003.), Sport consumer typologies: A critical review, Sport Marketing Quarterly, Vol. 12., No. 4., str. 206-216

13. Wasserberg, M., (2009.), Understanding Sports Spectators' Motives for Attending Live Events: A Study of Darts Fans in the UK, Birkbeck sport business centre, Vol. 2., No. 3., str. 2-79

14. Zagnoli, P., Radicchi, E., (2010.), The football fan community as a determinant stakeholder in value co-creation, Physical culture and sport studies and research, Sport Management Laboratory, University of Florence, Italy, Vol L, str. 79-99 


\section{Internet:}

Deloitte, 2020 Sports industry outlook: https:/www2.deloitte.com/us/en/pages/technology-media-and-telecommunications/articles/sports-business-trends-disruption.html (02.09.2020.) 
Doris Delić, mag. oec.

ddelic03@gmail.com

Mario Pepur, PhD

University of Split, Faculty of Economics, Business and Tourism, Split, Croatia mpepur@efst.hr

\title{
IMPACT OF FAN SEGMENTATION ON REPURCHASE INTENTION
}

Received: February 13, 2020

Accepted: August 26, 2020

https://doi.org/10.46458/27121097.2020.26.29

\section{Preliminary communication}

\begin{abstract}
The last two decades have shown a major and complex transformation of sport into a business that places sport industry among the most significant industries in the developed world. The increasing application of recent business principles in the sport industry is an inevitable consequence of today's understanding of sport. The sport industry is the global market for various sport related products. In order for manufacturers and providers of sport products and services to create certain advantages over other competitors, they are forced to explore the existing market and make its segmentation. Segmentation is the process of dividing a market of consumers into individual groups based on their characteristics, preferences and desires. Only satisfied customers develop loyalty to the manufacturer or service provider and, as such, repeat their purchase frequently. The data used in the paper was collected via an on-line survey among HNK Hajduk fans. The paper analysed fan segments and investigated the impact of segmentation on repurchase intention. Segment differences were tested with respect to the revisit intention on football match, the intention to repurchase the official club's products and services, and the intention to repurchase the club's sponsor's products and services. The results of the survey indicated that fans could be grouped into five different segments and that there was a statistically significant difference between segments in terms of repurchase intention.
\end{abstract}

Keywords: sports marketing, market segmentation, repurchase intention, football fans;

JEL: M31 